\title{
Enlightenment of American Real Estate Financial Innovation for China
}

\author{
Yijun Gong ${ }^{1}$, Yue Zeng ${ }^{2}$, Jianjun Xie ${ }^{1}$ \\ ${ }^{1}$ School of Economics, Sichuan University, Chengdu, Sichuan Province, China. \\ ${ }^{2}$ Sichaun Business Vocational College, Chengdu, Sichuan Province, China.
}

Keywords: America, China, real estate financial innovation, enlightenment

\begin{abstract}
At present, China is in the critical period of real estate financial innovation. It is urgent to learn relevant experience from American and European countries, in order to identify the correct direction and choose a proper path of real estate financial innovation. As the most important birthplace of real estate financial innovation, the United States has accumulated valuable experiences in promoting the financial innovation of real estate industry. Measures about diversified financial institutions and financial products, housing credit mode innovation and housing mortgage loan guarantee mechanism have extremely important referential significance to the promotion of real estate financial innovation in China.
\end{abstract}

\section{Development Process of Real Estate Financial Innovation in the United States}

\subsection{The stage of free exploration}

Before the popularity of keynesianism in 1930s, the mainstream economic theory in the world held that the government should not intervene in economic development; the market should play its decisive role in the allocation of resources. The world economy was in a laissez-faire state at that time. Under the guidance of self owned economic theory, and drawing lessons from the savings and loan association originated in the UK in eighteenth century, the real estate finance in the US embarked on a way of self exploration, and achieved good results. American savings and loan association adopted the membership mechanism. Stockholder's equity was determined by his membership contribution of capital. The capital pool of the association was mainly composed of membership contribution and deposit composition. On that basis, housing loans were issued to association members who demand for houses. Through the interest margin, the association could realize gains and appreciation in asset value. From 1870s to early twentieth century, the housing needs of Americans continued to increase with the speed up urbanization process. Under the background of constantly rising housing prices, more and more Americans chose to buy houses through housing mortgage loans and other forms of loans. Finance companies like life-insurance companies, folk mutual-help financial institutions and mortgage companies began to appear. Buyers could choose different kinds of loan products. The multi-layer market and diversified institutions became the key and development direction of real estate financial market in the United States.

\subsection{The stage of government intervention}

From 1929 to 1933, economic crisis that originated in the United States broke out in major capitalist countries of the world. It is called the Great Depression. The Great Depression exposed various defects of market. Main developed countries and mainstream economists began to reflect and criticize the economic liberalism, and gradually recognized the necessity of government intervention in economic development. The U.S. government also realized the limitations of market from the serious crisis in real estate finance caused by the Great Depression. Therefore, a series of measures were adopted to regulate the real estate financial market. The US government began to intervene in the real estate financial market through a series of effective measures. The real estate financial system in the US was initially formed; its economy began to go out of the recession under the guidance of the "visible hand" of the government. 


\subsection{The neo liberalism stage}

In 1970s, the liberal tide reoccurred after the failure of government's intervention and mediation in economy. Governments and economists began to attach great importance to the spontaneous adjustment function of the market. Governments cut down their intervention in the economy. The neo liberalism rose. Compared with the initial liberal stage, neo liberalism admitted proper regulations of the government. In 1970s, the base interest rates of America were continuously increasing, resulting in economic stagflation: economic stagnation and serious inflation. Real estate savings and loan institutions were affected by economic stagnation and fluctuation, led to big crisis in the real estate market. In 1980, President Carter signed The Depository Institutions Deregulation and Monetary Control Act of 1980 (hereinafter referred to as the Act of 1980) to deregulate the interest rate. This act eased the crisis faced by financial institutions to a certain extent, and helped real estate savings and loan institutions gradually get out of the trouble. In 1982, the federal government gradually lifted the interest rate cap, deregulated the business of savings and loan institutions, and allowed shall deposit institutions to issue mortgage loans with floating interest rates. These loose financial policies promoted innovations in American real estate finance industry. The real estate finance developed towards liberalization.

\subsection{The stage of crisis and recovery}

Before the mid of 1990s, most U.S. financial institutions only offered real estate mortgage to high income population. Low income people with "subprime" credit evaluation level were difficult to get loans. The U.S. government always encouraged citizens to buy houses. In the middle of 1990s, most middle-class families had bought houses already; real estate credit businesses began to decline. Thus, loan institutions began to reduce mortgage standards in order to attract more customers. The customer groups were gradually expanded to low income earners who were evaluated as "subprime". At the same time, the U.S. government shifted the focus of real estate development to low income groups, and issued support policies. These measures led to rapid development of subprime business in real estate, and gradually lifted the housing prices. But after a series of monetary easing polices, the Federal Reserve began to raise interest rates in 2006. Housing prices began to decline; low income borrowers with credit evaluation of "subprime" were under increasingly repayment pressure. The rising of subprime default rate led to losses and bankruptcy of many financial institutions. Finally in 2008, the sub-prime crisis broke out. Subsequently, the U.S. government took remedial measure on all levels, such as strengthening the supervision of real estate market and the reform of real estate mortgage market, so as to prevent the irrational expansion of financial institutions. The United States gradually went out of the shadow of subprime crisis; the real estate market and real estate financial innovation also revitalized over a relatively short span of time.

\section{Main Characteristics of Real Estate Financial Innovation in the United States}

\subsection{Diversification of real estate financial institutions and products}

Diversification of real estate financial institutions and products is a relatively obvious characteristic of American real estate financial system. The mutual cooperation of financial institutions, commercial financial institutions and policy financial institutions are symbols of diversified financial institutions. Through real estate trust, real estate investment funds and financial products, they promote the development and innovation of real estate finance industry together. The United States is a typical country of market economy. Therefore, private financial institutions like savings and loan associations, commercial banks and insurance companies occupy the main position of the real estate financial system. American real estate financial institutions have released a lot of real estate financial products, and solved economic problems about real estate development and innovation at all levels through market mechanisms. Most American buyers get housing loans from these private financial institutions. Meanwhile, two typical policy financial institutions, Fannie Mae and Freddie Mac, namely the Federal National Mortgage Association and Federal Home Mortgage 
Corporation, were also established in the real estate financial system. In addition, measures include ensuring the supply of housing mortgage loan to meet the requirements of buyers, guaranteeing the sufficient funds for housing estate construction, and enhancing the liquidity of mortgage funds to achieve the overall regulation and management of real estate financial market, also play an extremely important role in the realization of the "home ownership" goal.

\subsection{Housing credit mode dominated by housing mortgage loans}

The United States is the birthplace of housing mortgage loans; housing mortgage loans occupy the most important position in American housing credit mode. For American residents, housing mortgage loan is a common choice in house purchasing. Buyers get housing loans through mortgage the house to financial institutions, and repay the principal and interest in time. If the buyer cannot pay the principal and interest at the due, the mortgaged property will be sold by the financial institution to pay off the loan. Data show that, housing mortgage loans are the second largest debt of all financial institutions in America, and surpassed only by the government debt of the United States. In addition, the housing mortgage loan operation mechanism in the U.S. is relatively mature. The first and second markets closely cooperate and work well. So the housing loan market is competitive, and can design all kinds of mortgage products in line with the condition of the United States. The mature mortgage market not only fully meets the loan demands of American buyers, but also encourages real estate financial institutions to innovate and enrich financial products under the stimulation of profit and government policies, so as to promote the enrichment and improvement of American financial real estate models and products.

\subsection{Housing mortgage loan guarantee mechanism for middle and low income residents}

In order to ensure the rapid and healthy development of the real estate market, the U.S. set up a complete real estate financial system, including the qualification inspection of buyers, mortgage institutions and housing mortgage loan guarantee institutions. As the name suggests, the housing mortgage loan is the loan that borrowers obtained from housing financial institutions through the mortgage of private houses; these houses can be traded on the market and have certain values. But generally speaking, it is difficult for middle and low income people to offer houses with equivalent values. They cannot get housing mortgage loan, which will cause the decline of real estate market demands and the depression of real estate market. In order to prevent the real estate market from this vicious circle, the federal government established the Federal Housing Administration in 1934. The agency charged management fees, and provide guarantee and insurance to low-income persons who have the willingness to lend but do not have corresponding pledge. The Federal Housing Administration effectively protects financial institutions from financial loss caused by customers who are unable to pay off the loan before the due time. Thanks to the establishment of housing mortgage loan guarantee mechanism, low-income people who cannot afford house-purchasing could buy their own houses, and the risks faced by housing loan financial institutions are greatly reduced.

\section{The Enlightenment of American Real Estate Financial Innovation to China}

\subsection{The combination of government and market regulation}

Moderate government regulation and complying with market economy laws are two basic principles in the development of real estate finance. Firstly, the principle of marketization must be adhered to gradually deregulate the real estate market and real estate finance, and to create a fully competitive environment. Thus, we can achieve the goal of "survival of the fittest", and maintain the vitality, motivation and efficient operation of real estate finance industry. For example, marketization is the most obvious feature of American real estate finance industry. Commercial financial institutions play the main role; the development of real estate finance is regulated by market. In order to achieve the smooth and healthy development of real estate finance, China must adhere to the principles of combining market regulation with government regulation, respecting basic market laws, and abiding by intervention and policies of the government. Through tax incentives, financial 
subsidies, guarantee measures, legislation strengthening and other measures, problems caused by market failure can be solved, so as to standardize market order, control the risk of financial institutions, and guarantee the house purchasing ability of residents from all income levels.

\subsection{Adhering to the diversified real estate financial mode}

From related development experience of the United States, it can be seen that the diversified real estate finance mode plays an extremely important role in the development of real estate finance industry and the protection of residents' housing rights. For example, generally speaking, the real estate finance mode in America is established on the basis of housing mortgage loan mode, and supported by policy-based finance. The commercial financial mode can solve financial problems of the real estate industry more efficiently by integrating market resources. Diversified real estate financial models are conducive to the full development of real estate finance, and can ensure the social equity and stability through the coordination of various modes. Therefore, China's real estate financial mode should also focus on the main part, and pays attention to diversified development methods in accordance with national conditions and industrial development needs.

\subsection{Attaching equal importance to financial innovation and risk prevention}

The U.S. subprime crisis swept the world in 2008 shows that, the government must pay attention to risk prevention while promoting the innovation of real estate finance. Real estate financial innovation can promote the efficient operation of the real estate financial market, and improve the enthusiasm of the real estate financial institutions; but innovation also brings risks. The coexistence of high risk and high income is a double-edged sword. Generally speaking, high risk is often accompanied by the high return rate of financial derivatives. But these risks are hidden, and are not easy to be found in time. These crises lurking in the real estate financial innovation were ignored for a long time, but they finally broke out. China is in the key period of real estate finance development; the risk prevention mechanism in our country is not solid enough. Therefore, in the process of promoting real estate financial innovation, we must attach great importance to the existence of risks; while avoiding systemic risks caused by economic and political turmoil, we also need to guard against systemic risks caused by the shortage of funds and credit problems for all time.

\subsection{Sticking to the principle of moderate innovation}

Financial derivatives created by financial innovation have functions of value discovery and risk transfer; they can transfer financial risks, like credit risk and price risk to a certain extent. For example, financial innovation can improve efficiency through reducing agency costs, information asymmetry and transaction costs; it can also reduce financial risks through increasing risk sharing opportunities. Therefore, on the basis of real estate financial innovation, the risk of real estate financial market can be transferred and dispersed to a certain extent. However, if the real estate financial innovation exceeds a certain level, the real estate financial industry may become over dependence on bank loans, resulting in sharp increase of real estate enterprises' loans and credit asset bubbles, and finally led to financial risks. Therefore, in the process of promoting real estate finance innovation, China must avoid crises caused by excessive innovation, adhere to the principle of moderation, and strive to promote financial innovation and development under the premise of minimize real estate risks.

\section{References}

[1] H.B. Chen, American real estate financial policies and enlightenment to China, J. China Real Estate Finance. 2 (2006).

[2] J. Gao, Analysis of risk prevention procedures in American real estate credit system, J. Forum of World Economics \& Politics. 6 (2007).

[3] Y.K. Zhu, Y. Li, Inspiration of American real estate financial mechanism, J. China Real Estate Finance. 2 (2003). 
[4] X.F. Huo, Development problems of Chinese real estate financial system and countermeasures, J. Northern Economy. 8 (2012).

[5] L.J. Liu, T. Zhang, The successful experience and inspiration of financial supervision cooperation in foreign countries, J. Hainan Finance. 7 (2011).

[6] L.Q. Guo, L.Z. Liu, Study on financial innovation in Chinese real estate industry, J. Seeking Truth. 3 (2015).

[7] Y.Y. Li, C.H. Shang, H. Jin, The dynamic coupling development of financial innovation and real estate industry, J. Research on Economics and Management. 38 (2017). 